\title{
A New Deep-sea Eelpout, Hadropogonichthys leptopus (Osteichthyes: Perciformes: Zoarcidae), from the Pacific Ocean off Japan
}

\author{
Yoshihiko Machida ${ }^{1}$, Gento Shinohara ${ }^{2}$ and Suguru Ohta ${ }^{3}$ \\ ${ }^{1}$ Faculty of Science, Kochi University, 2-5-1 Akebono-cho, Kochi, 780-8063 Japan \\ E-mail: machida@cc.kochi-u.ac.jp \\ ${ }^{2}$ National Science Museum (Nat. Hist.), 3-23-1 Hyakunin-cho, \\ Shinjuku-ku, Tokyo, 169-0073 Japan \\ E-mail:s-gento@kahaku.go.jp \\ ${ }^{3}$ Ocean Research Institute, University of Tokyo, 1-15-1 Minamidai, \\ Nakano-ku, Tokyo, 164-0014 Japan \\ E-mail:sohta@ori.u-tokyo.ac.jp
}

(Received 26 July 2003; Accepted 23 February 2004)

\begin{abstract}
A new deep-sea eelpout, Hadropogonichthys leptopus, representing the second species in the genus, is described on the basis of 25 specimens from the Pacific Ocean off central and northern Honshu, Japan, at depths ranging from 1115 to $1948 \mathrm{~m}$. This species differs from $H$. lindbergi Fedorov, 1982 from the Fourth Kuril Strait, Russia, in having simple or bifid cirri in single rows on the mandibular canal and ventral branch of the suborbital canal, short and slender pelvic fins, three postorbital pores, 14-16 pectoral fin rays, and two nub-like pyloric caeca.
\end{abstract}

Key Words: deep-sea fish, Zoarcidae, Hadropogonichthys leptopus, new species, northwest Pacific.

\section{Introduction}

The deep-sea eelpout genus Hadropogonichthys Fedorov, 1982 was originally described on the basis of two specimens of $H$. lindbergi Fedorov, 1982 trawled from the Fourth Kuril Strait at a depth of about $600 \mathrm{~m}$ (Fedorov 1982; Toyoshima 1985; Anderson 1994). Fedorov (1982) defined the genus as follows: cephalic lateralis pores small; stout, fleshy cirri between cephalic lateralis pores, and on upper lip and lower side of head; and pelvic fins bifurcate distally. Toyoshima (1985) followed Fedorov (1982) in his diagnosis of the genus. In a world revision of the family Zoarcidae, Anderson (1994) redefined Hadropogonichthys based on meristic counts, the arrangement and morphology of head cirri, the greatly thickened and ensheathed pelvic fins, and osteological features. He also examined a hitherto unreported specimen of Hadropogonichthys from Japan, preserved in the National Science Museum, Tokyo (NSMT), but nevertheless considered the genus to be monotypic (Anderson 1994).

During our studies on the deep-sea ichthyofauna around Japan, we obtained 25 specimens referable to this genus. Subsequent study of these specimens, including that examined by Anderson (1994) (above), revealed that the Japanese Hadropogo- 
nichthys specimens are distinct from $H$. lindbergi. In this paper they are described as a new species, Hadropogonichthys leptopus.

\section{Materials and Methods}

Methods for measurements follow Peden and Anderson (1978). Terminology of the cephalic lateralis pores follows Anderson (1994). Counts of vertical fin rays and vertebrae, including the urostyle, were taken from radiographs. Head length, standard length, and total length are abbreviated as HL, SL, and TL, respectively. Specimens are deposited in the Laboratory of Marine Biology, Kochi University (BSKU) and the Department of Zoology, National Science Museum, Tokyo (NSMT). The single paratype of $H$. lindbergi, held in the Zoological Institute, Russian Academy of Sciences (ZIN), was also examined.

Hadropogonichthys leptopus sp. nov.

[New Japanese name: Wadatsumi-genge]

(Figs 1-4, Table 1)

Hadropogonichthys lindbergi: Anderson 1994: 60, fig. 110 (in part).

Materials examined. Holotype: NSMT-P 57227, male, $211.0 \mathrm{~mm}$ SL, $36^{\circ} 45.41^{\prime} \mathrm{N}$, $141^{\circ} 43.16^{\prime} \mathrm{E}$ to $36^{\circ} 45.06^{\prime} \mathrm{N}, 141^{\circ} 42.78^{\prime} \mathrm{E}$, Pacific Ocean off Ibaraki Prefecture (Pref.), Honshu Island, Japan, $1408 \mathrm{~m}$, otter trawl, R/V Tanshu-maru, 19 Apr. 1996 (in NSMT). Paratypes (24 specimens): BSKU 19655, female, $130.2 \mathrm{~mm} \mathrm{SL,} 34^{\circ} 04.4^{\prime} \mathrm{N}$, $140^{\circ} 01.5^{\prime}$ E, Pacific Ocean off Shizuoka Pref., Honshu Island, Japan, R/V Soyo-maru, bottom trawl, 1270-1280 m, 11 Oct. 1965; BSKU 19848, male, $96.7 \mathrm{~mm} \mathrm{SL}, 34^{\circ} 10.0^{\prime} \mathrm{N}$, $140^{\circ} 06.1^{\prime} \mathrm{E}$, off Shizuoka Pref., R/V Soyo-maru, bottom trawl, 1410-1450 m, 5 July 1968; BSKU 19989, male, $132.7 \mathrm{~mm}$ SL, $34^{\circ} 00.6^{\prime} \mathrm{N}, 140^{\circ} 02.4^{\prime} \mathrm{E}$, off Shizuoka Pref., R/V Soyo-maru, bottom trawl, $1115 \mathrm{~m}, 10$ Oct. 1969; BSKU 20235, female, $114.7 \mathrm{~mm}$ SL, $34^{\circ} 05.0^{\prime} \mathrm{N}, 140^{\circ} 03.7^{\prime} \mathrm{E}$, off Shizuoka Pref., R/V Soyo-maru, bottom trawl, $1250-1270 \mathrm{~m}$, 20 June 1972; BSKU 82229, female, $191.3 \mathrm{~mm}$ SL, $38^{\circ} 42.0^{\prime} \mathrm{N}, 143^{\circ} 01.6^{\prime} \mathrm{E}$ to $38^{\circ} 40.6^{\prime} \mathrm{N}$, $143^{\circ} 00.2^{\prime} \mathrm{E}$, Pacific Ocean off Miyagi Pref., Honshu Island, Japan, R/V Tansei-maru (cruise KT-85-11), 3 m ORE-beam trawl, 1642-1659 m, 12 Aug. 1985; NSMT-P 49050, 10 males and 1 female, $123.0-219.0 \mathrm{~mm}$ SL, $36^{\circ} 28.43^{\prime} \mathrm{N}, 141^{\circ} 24.18^{\prime} \mathrm{E}$ to $36^{\circ} 27.27^{\prime} \mathrm{N}$, $141^{\circ} 32.20^{\prime} \mathrm{E}$, off Ibaraki Pref., R/V Wakataka-maru, otter trawl, 1464-1537 m, 10 Nov. 1995; NSMT-P 55828, 2 males and 4 females, 148.0-207.0 mm SL, data as for holotype;

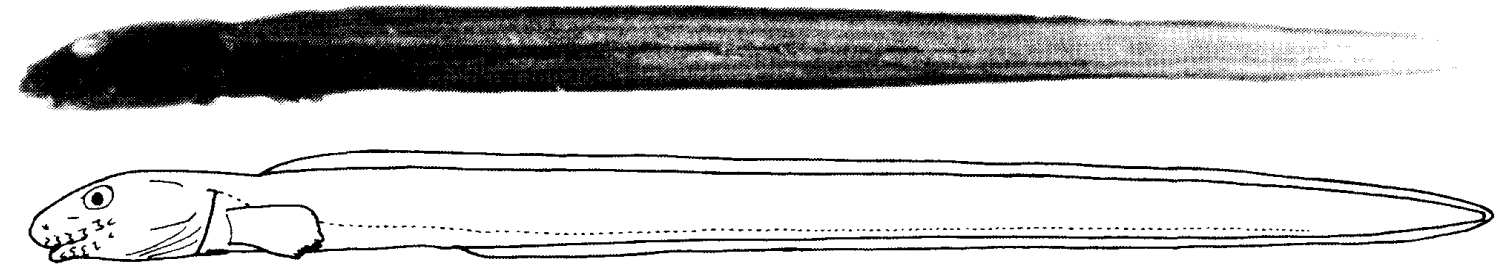

Fig. 1. Hadropogonichthys leptopus sp. nov., holotype, NSMT-P 57227, male, $211 \mathrm{~mm}$ SL. The sketch shows the course of lateral line. 
NSMT-P 55914, 1 male and 1 female, $190.0-218.0 \mathrm{~mm}$ SL, $36^{\circ} 25.23^{\prime} \mathrm{N}, 141^{\circ} 32.52^{\prime} \mathrm{E}$ to $36^{\circ} 31.04^{\prime} \mathrm{N}, 141^{\circ} 43.61^{\prime} \mathrm{E}$, off Ibaraki Pref., R/V Wakataka-maru, otter trawl, 1845-1948 m, 10 Nov. 1995.

Non-type specimen: NSMT-P 18991, 1 female, $147.0 \mathrm{~mm} \mathrm{SL}, 35^{\circ} 03.5^{\prime} \mathrm{N}, 139^{\circ} 18.1^{\prime} \mathrm{E}$, Sagami Bay, Honshu Island, Japan, trawl, 1400 m, 11 July 1978.

Comparative material. Hadropogonichthys lindbergi: ZIN 45322 (paratype), female, $284 \mathrm{~mm}$ SL, see Fedorov (1982) for detailed collection data.

Diagnosis. A species of Hadropogonichthys with the following combination of characters: suborbital bones 10, canal with 9-11 pores; preoperculomandibular pores 8 or 9 ; postorbital pores 3 ; interorbital pore present or absent; occipital pores
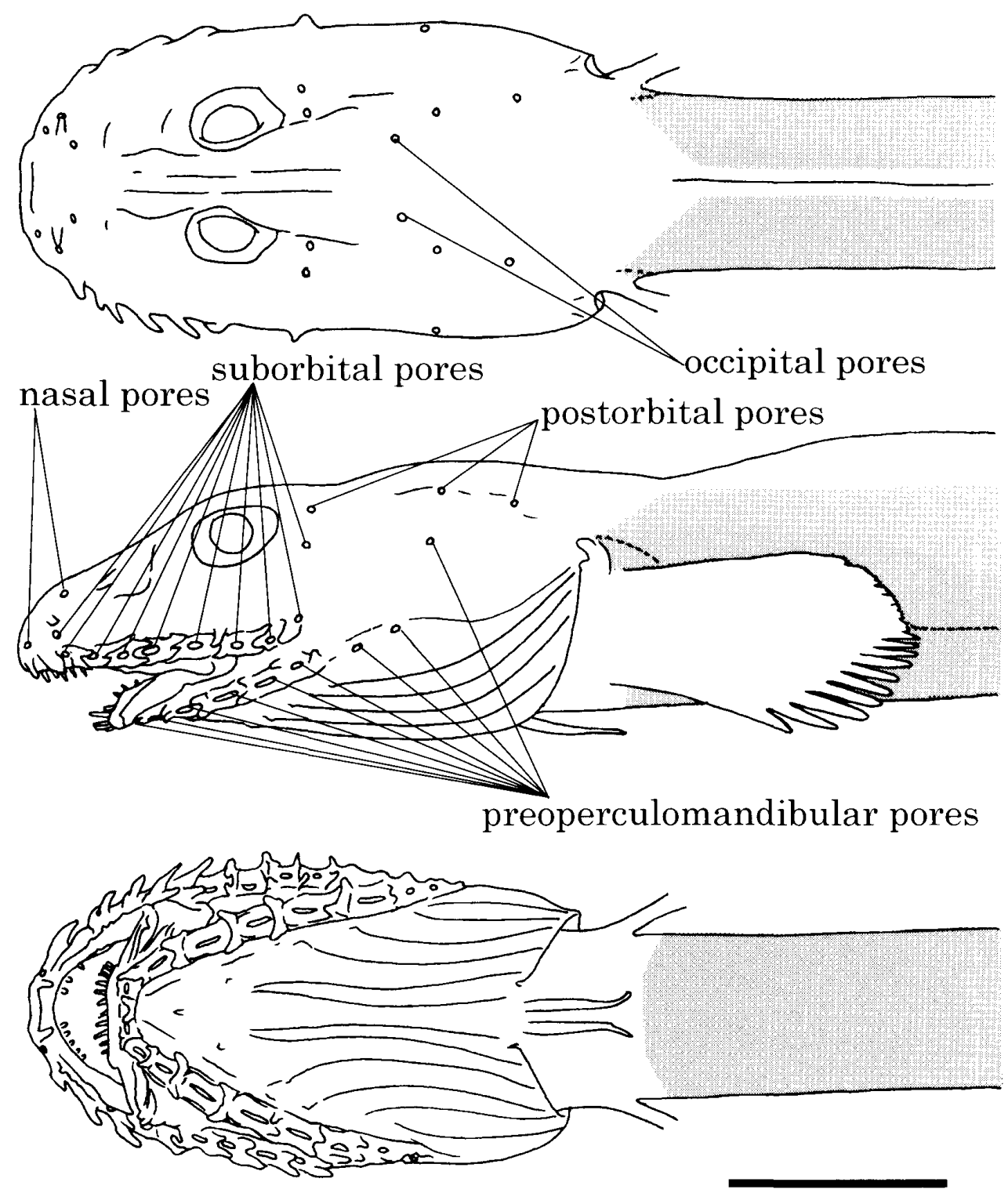

Fig. 2. Squamation and seismosensory head pores of Hadropogonichthys leptopus sp. nov., holotype, NSMT-P 57227, male, $211 \mathrm{~mm} \mathrm{SL}$. The zone of squamation is shaded. Scale bar $10 \mathrm{~mm}$. 
2; simple or bifid cirri in single rows on mandibular canal and ventral branch of suborbital canal; no cirri on gular region; pectoral fin rays 14-16 (mostly 15); pelvic fins slender, short, each with 2 rays; pseudobranchs, pyloric caeca, lateral line, and vomerine and palatine teeth present; gill rakers $2-3+11-13=14-16$; anal fin rays $120-129$.

Description. Counts and proportional measurements (\% TL) given in Table 1. Following measurements in $\%$ SL (data of holotype given first, followed by those of paratypes in parentheses): HL 13.6 (12.5-15.6); body height at anal fin origin 5.0 (3.9-6.5); predorsal length 15.3 (14.7-18.8); preanal length 27.6 (25.7-31.2); pectoral fin length 7.6 (6.2-9.3), gill slit length 4.6 (3.0-5.1); upper jaw length $11.8(9.8-11.1)$; snout length 5.2 (4.0-5.3); eye diameter 2.7 (2.3-3.2); interorbital width 2.0 (1.5-2.4); pelvic fin length $2.4(1.8-3.5)$. Pectoral fin basal width/pectoral fin length ratio $34.4 \%$
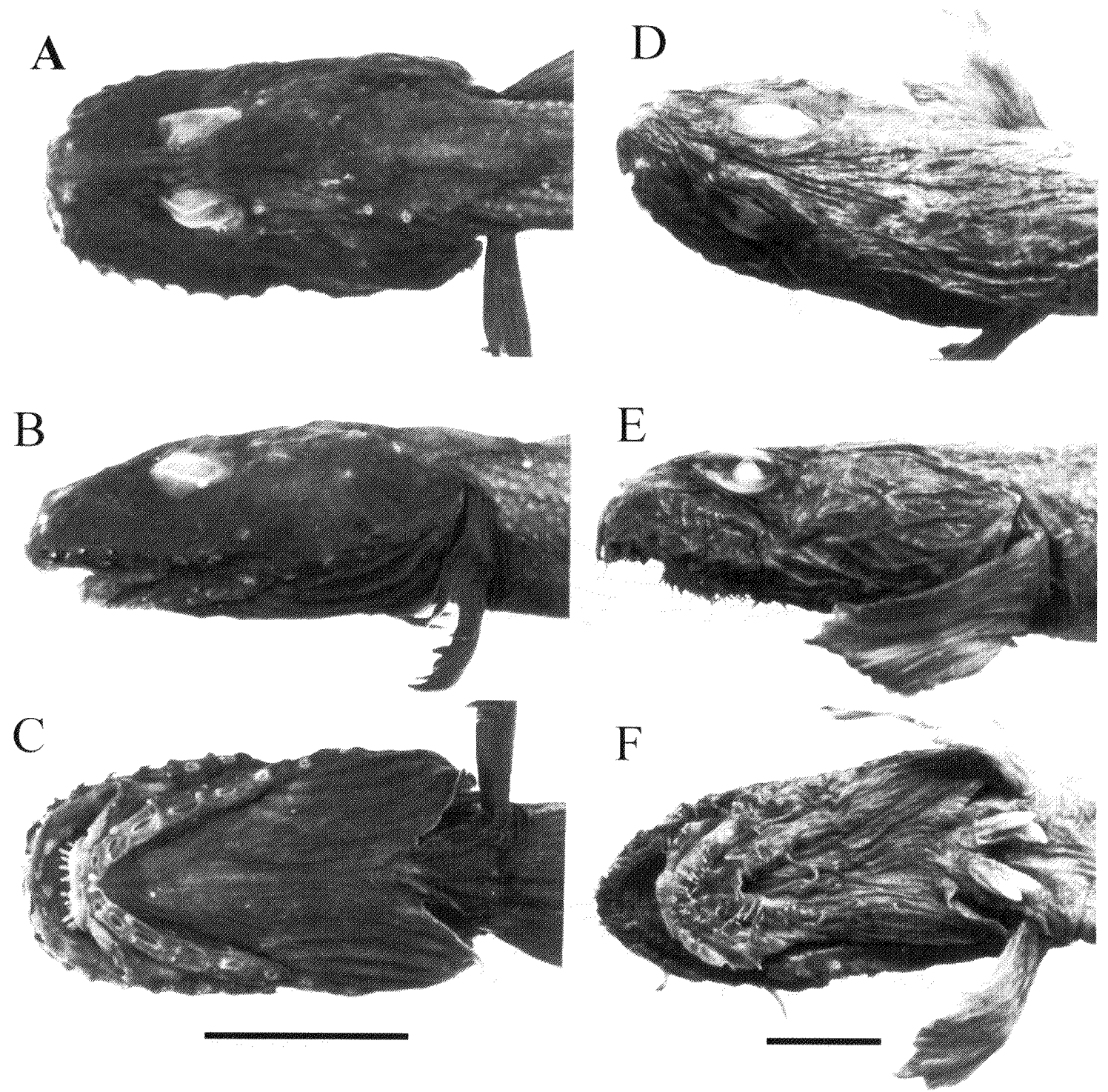

Fig. 3. Comparisons of dorsal, lateral, and ventral head views in Hadropogonichthys. A-C, $H$. leptopus sp. nov., holotype; D-F, H. lindbergi Fedorov, 1982, paratype. Scale bars $10 \mathrm{~mm}$. 
$(29.4-45.7 \%)$.

Body shallow, elongate (Fig. 1). Head short. Snout rounded, much longer than eye diameter (Fig. 2). Eye elliptical, diameter slightly greater than fleshy interorbital width. Mouth small. Posterior end of upper jaw reaching nearly to point below middle of eye. Upper lip continuous at symphysis. Lower jaw short, included within upper jaw, strongly adnate at dentary symphysis. Nostril tube developed. Branchiostegal membranes united to isthmus. Gill opening wide, extending ventrally below level of lower end of pectoral fin base. Nine or 10 fleshy cirri arranged in single row on ventral branch of suborbital canal from near tip of snout to slightly behind last pore; cirri between pores large, distinct, bifid (Figs 2, 3). Five cirri arranged in single row on mandibular canal from near symphysis to posterior end of dentary; anteriormost cirrus extremely short, simple; other 4 cirri large, distinct, bifid, situated between mandibular pores (Figs 2, 3). No cirri on lips and branchiostegal membranes.

Teeth small, rod-like, sparse on both jaws. Upper jaw teeth in single row. Lower jaw teeth in 2 rows, somewhat irregular near symphysis. Vomerine teeth 4-6. Palatine teeth 46 on palatine, arranged in single row. Oral valve weak, not reaching vomer. Pseudobranch filaments short. Gill rakers short, triangular.

Cephalic lateralis pores well developed (Figs 2,3), those between cirri on both jaws large, slit-like. Postorbital pores 1, 3, and 4 present. Nasal pores 2. Interorbital pore 0 or 1 (usually absent). Occipital pores 2 . Suborbital pores on ventral branch below eye $8-9$ (mostly 8 ), those on ascending branch behind eye 1-3 (mostly 2 ). Pre-

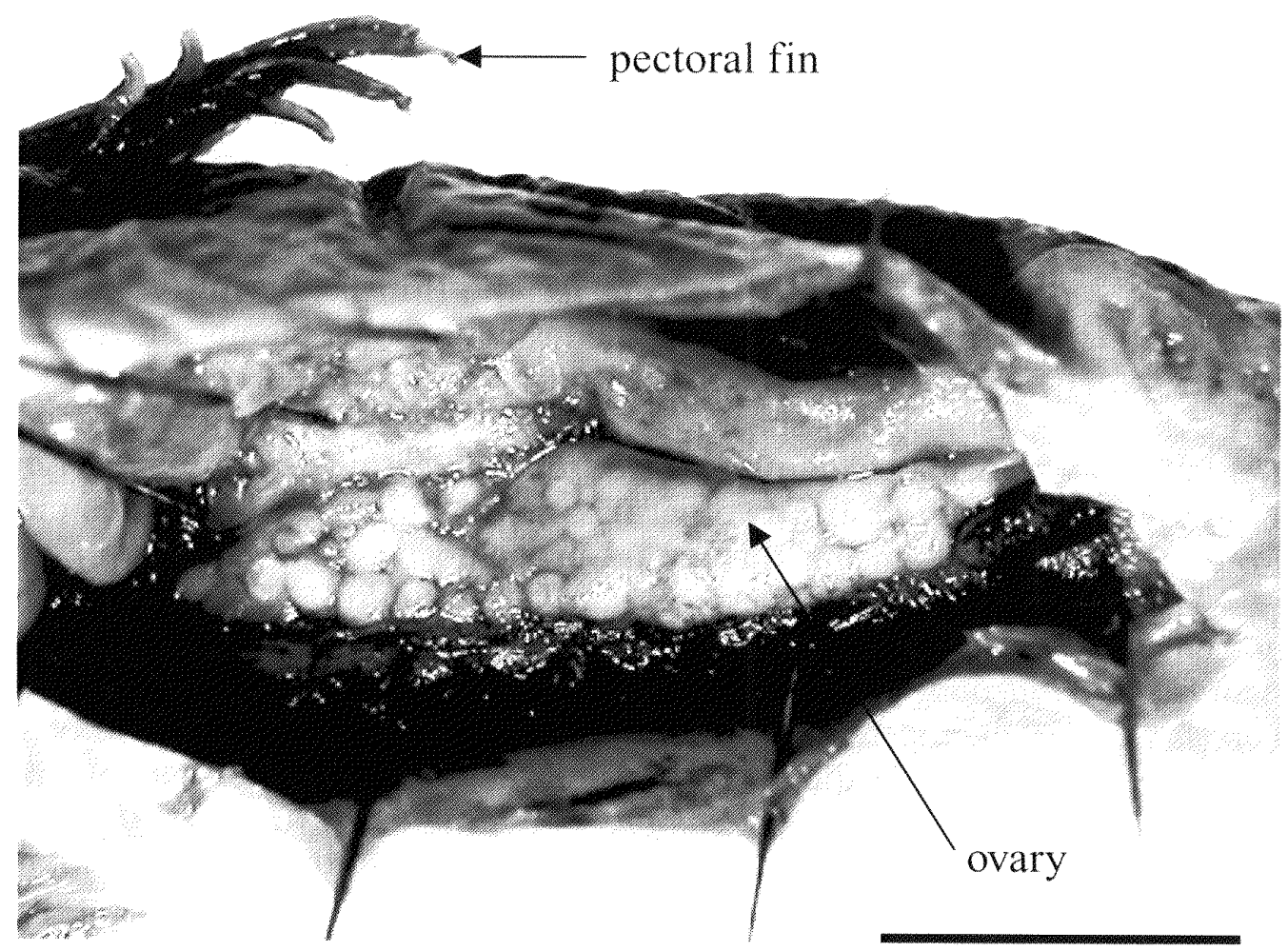

Fig. 4. Ovary of Hadropogonichthys leptopus sp. nov., paratype, BSKU 82229, $191.3 \mathrm{~mm}$ SL. Scale bar $5 \mathrm{~mm}$. 
operculomandibular pores 8 or 9 (mostly 9): 4 or 5 (mostly 5) arising from dentary, 1 from anguloarticular, 3 from preopercle.

Body covered with scales, except paired fins and dorsum before dorsal fin origin. Bases of vertical and pectoral fins also scaleless. Lateral line single, ventral, complete. Dorsal fin originating slightly behind pectoral fin base. Anal fin origin below 14th-18th dorsal fin ray (mode 17th). Pectoral fin rounded, relatively short. Pelvic fin slender with 2 rays, tip pointed (Fig. 2). Epipleural ribs usually present from vertebra 3,4 , or 5 (mode 4) to penultimate precaudal vertebra, rarely absent from last 3 precaudal vertebrae, rarely present on last precaudal vertebra. First dorsal fin pterygiophore associated with 7th or 8th vertebra (mode 8th); no free dorsal pterygiophores. Pyloric caeca 2, nub-like.

Color in alcohol. Uniformly dark brown; head, paired fins, and bases of vertical fins much darker. Oral and branchial cavities pale brown. Stomach pale. Peritoneum dark brown.

Etymology. Named from the Greek leptos (=thin)+pous (=foot) in reference to the pelvic fin character.

Distribution. Known only from the Pacific Ocean off central to northern Honshu, Japan, at depths $1115-1948 \mathrm{~m}$.

Biological note. All females ( $>104 \mathrm{~mm} \mathrm{SL}$ ) had eggs. One of the paratypes, BSKU 82229, had about 130 eggs ranging from 0.2 to $1.0 \mathrm{~mm}$ in diameter, most being larger than $0.5 \mathrm{~mm}$ (Fig. 4).

\section{Discussion}

The rare eelpout genus Hadropogonichthys has been thought to be monotypic, comprising only its type species $H$. lindbergi, for over 20 years (see Toyoshima 1985; Anderson 1994), being redefined by Anderson (1994) on the basis of new material from Japan, in addition to other known specimens (holotype and paratype). Hadropogonichthys leptopus agrees in most respects with the definition of Hadropogonichthys (sensu Anderson 1994), except for the thin pelvic fin (greatly thickened in $H$. lindbergi), absence of cirri on the branchiostegal membrane (presence), and 120-129 anal fin rays (112-114). According to Anderson (1994), the monotypic zoarcid genus Lyconema (type species L. barbatum Gilbert, 1896, recorded from Oregon to Baja California) is similar to Hadropogonichthys in having cirri on the head; however, L. barbatum has two parallel rows of simple, filamentous cirri on the lower jaw (often present on throat and branchiostegal membranes in adults). Because $H$. leptopus is more similar to $H$. lindbergi than to $L$. barbatum (owing to the presence of circumoral cirri in the two former species), the new species should be included in Hadropogonichthys. Consequently, some diagnostic characters of Hadropogonichthys should be redefined as follows: pelvic fin rays 2, thin or thick; cirri present or absent on branchiostegal membrane; vertebrae 132-146.

Within Hadropogonichthys, $H$. leptopus is distinguished from $H$. lindbergi by having a lower number of postorbital head pores ( 3 vs. 4 in the latter, but known to be variable in Zoarcidae; see Anderson 1994: 65), lower number of pectoral fin rays (14-16 vs. 19), pyloric caecae present ( 2 vs. 0 ), and a slightly greater snout length (29.6-38.1\% HL vs. $27.0-27.1 \% \mathrm{HL}$ ), in addition to differences in pelvic fin condition and cirri distribution. 
Anderson (1994) figured a Hadropogonichthys specimen (identified as $H$. lindbergi; NSMT-P 18991) collected from Sagami Bay, Pacific coast of Honshu Island, Japan. Although this specimen was badly damaged, it agrees closely with $\mathrm{H}$. leptopus in having simple or bifid cirri in single rows on the mandibular canal and ven-

Table 1. Comparison of Hadropogonichthys leptopus with H. lindbergi.

\begin{tabular}{|c|c|c|c|c|c|}
\hline & \multicolumn{3}{|c|}{ H. leptopus sp. nov. } & \multicolumn{2}{|c|}{ H. lindbergi* } \\
\hline & holotype & $\begin{array}{c}\text { paratypes } \\
(\mathrm{N}=24) \\
\text { range }\end{array}$ & $\begin{array}{l}(\mathrm{N}=25) \\
\text { mean }\end{array}$ & holotype & paratype \\
\hline $\mathrm{TL}(\mathrm{mm})$ & 212 & $97-221$ & & 367 & 290 \\
\hline \multicolumn{6}{|l|}{$\% \mathrm{TL}$} \\
\hline $\mathrm{HL}$ & 13.5 & $12.4-14.4$ & 13.5 & $13.9^{\mathrm{a}}$ & $14.1^{\mathrm{a}}$ \\
\hline Predorsal length & 15.2 & $14.5-17.2$ & 15.7 & 17.7 & 16.7 \\
\hline Preanal length & 27.4 & $25.0-28.9$ & 27.4 & 27.8 & 27.9 \\
\hline Body depth at anal origin & 5.0 & $3.9-6.5$ & 5.5 & 5.3 & 5.4 \\
\hline Pectoral fin length & 7.5 & $6.1-8.6$ & 7.4 & 7.0 & 7.9 \\
\hline \multicolumn{6}{|l|}{$\% \mathrm{HL}$} \\
\hline Head width & 47.2 & $32.0-46.7$ & 37.7 & 58.4 & 45.2 \\
\hline Snout length & 38.1 & $29.6-38.1$ & 33.8 & 27.1 & 27.0 \\
\hline Upper jaw length & 41.2 & $28.2-38.5$ & 34.3 & 40.4 & 36.4 \\
\hline Lower jaw length & 43.0 & $38.8-46.5$ & 41.8 & 48.2 & 42.3 \\
\hline Eye diameter & 19.6 & $17.1-21.5$ & 19.8 & 17.1 & 17.2 \\
\hline Pectoral fin length & 55.9 & $46.0-62.0$ & 54.9 & 50.2 & 56.2 \\
\hline Pelvic fin length & 17.8 & $13.0-24.8$ & 17.8 & 14.1 & 18.9 \\
\hline Length of gill opening & 33.6 & $26.8-33.1$ & 30.3 & 41.6 & 36.9 \\
\hline \multicolumn{6}{|l|}{ Counts } \\
\hline Dorsal fin rays & 135 & $131-140$ & 134.2 & $128^{\mathrm{b}}$ & $126^{\mathrm{b}}$ \\
\hline Anal fin rays & 123 & $120-129$ & 124 & $114^{\mathrm{b}}$ & $112^{\mathrm{b}}$ \\
\hline Caudal fin rays & 9 & $9-10^{c}$ & $9.1^{c}$ & 11 & 11 \\
\hline Pectoral fin rays & 15 & $14-16$ & 15 & 19 & 19 \\
\hline Pelvic fin rays & 2 & 2 & 2 & 2 & 2 \\
\hline Branchiostegals & 6 & 6 & 6 & 6 & 6 \\
\hline Gill rakers & $3+12=15$ & $\begin{array}{c}2-3+11-13 \\
=14-16\end{array}$ & 15 & $\begin{array}{l}1+1+12 \\
=14\end{array}$ & $\begin{array}{l}1+1+11 \\
=13\end{array}$ \\
\hline Total vertebrae & $\begin{array}{l}23+119 \\
=142\end{array}$ & $\begin{array}{l}23-26+113-123 \\
\quad=136-146\end{array}$ & 140.6 & $\begin{array}{l}24+110 \\
=134\end{array}$ & $\begin{array}{l}23+109 \\
=132\end{array}$ \\
\hline Suborbital pores & 10 & $9-11$ & 10 & 10 & $9-10$ \\
\hline Postorbital pores & 3 & 3 & 3 & 4 & 4 \\
\hline Nasal pores & 2 & 2 & 2 & 2 & 2 \\
\hline Interorbital pore & 0 & $0-1$ & 0.3 & 0 & 0 \\
\hline Occipital pores & 2 & 2 & 2 & 1 & 2 \\
\hline $\begin{array}{l}\text { Preoperculomandibular } \\
\text { pores }\end{array}$ & 9 & $8-9$ & 8.9 & 9 & 9 \\
\hline Pseudobranchial filaments & 4 & $4-5$ & 4.2 & $4-6$ & $4-6$ \\
\hline Pyloric caeca & 2 & 2 & 2 & 0 & 0 \\
\hline
\end{tabular}

* From Fedorov (1982).

${ }^{a}$ Estimated from original description and paratype.

${ }^{\mathrm{b}}$ Recounted from original description.

" Excluding NSMT-P 55828 (abnormal condition of seven caudal fin rays). 
tral branch of the suborbital canal, 16 pectoral fin rays, and slender pelvic fins (see also Anderson 1994, fig. 110).

Hadropogonichthys leptopus appears to be a widely distributed benthic inhabitant in the Pacific Ocean off central to northern Honshu Island, Japan (ca. $34-36^{\circ} \mathrm{N}, 1115-1948 \mathrm{~m}$ depths). Because $H$. lindbergi has been reported from Fourth Kuril Strait (ca. $49.5^{\circ} \mathrm{N}, 600-615 \mathrm{~m}$ depths), the new species may have a more southern and deeper distribution than the former.

Taxonomic remarks. Fedorov (1982) gave the head lengths of the holotype and paratype as $23.9 \% \mathrm{TL}$ and $24.1 \% \mathrm{TL}$, respectively. We examined the paratype, and found a head length of $14.0 \%$ TL. Therefore, we conclude that Fedorov's value [23.9\% TL] for the holotype is incorrect, and should be read as $13.9 \%$ TL. This is corroborated by Fedorov's illustration of the holotype. Fedorov (1982) showed fin ray counts as dorsal fin rays plus dorsal half of caudal fin rays, anal fin rays plus ventral half of caudal fin rays, and caudal fin rays for $H$. lindbergi, but the dorsal and anal fin rays were counted here on the basis of his data as shown in Table 1.

\section{Acknowledgments}

We are very grateful to Dmitry Pitruk (Marine Biological Institute, Russian Academy of Sciences) and Vladimir Fedorov and staff of the Ichthyological Laboratory (ZIN) for their assistance in making the paratype specimen of $H$. lindbergi available for examination. Our thanks go to the officers, crew, and scientists on board the R/Vs Tansei-maru (Ocean Research Institute, University of Tokyo), Tanshu-maru (Kasumi High School, Hyogo), and Wakataka-maru and Soyo-maru (National Fisheries Research Center) for their assistance in collecting specimens. Graham Hardy (Ngunguru, New Zealand) and Jeffrey M. Leis (Australian Museum) helped with English. This study was supported by a Grant-in-Aid to the second author from the Japan Society for the Promotion of Science (No. 13640706).

\section{References}

Anderson, M. E. 1994. Systematics and osteology of the Zoarcidae (Teleostei: Perciformes). JLB Smith Institute of Ichthyology, Ichthyological Bulletin 60: 1-120.

Fedorov, V. V. 1982. A new eelpout, Hadropogonichthys lindbergi Fedorov, gen. et sp. nov. (Zoarcidae), from the bathyal depths of the Fourth Kuril Strait. Voprosy Ikhtiologii 22: 722-729. [In Russian]

Peden, A. E. and Anderson, M. E. 1978. A systematic review of the fish genus Lycodapus (Zoarcidae) with decriptions of two new species. Canadian Journal of Zoology 56: 1925-1961.

Toyoshima, M. 1985. Taxonomy of the subfamily Lycodinae (family Zoarcidae) in Japan and adjacent waters. Memoirs of the Faculty of Fisheries, Hokkaido University 32: 131-243. 